\title{
QUANTITATIVE SPECTROSCOPIC INVESTIGATION OF LOSARTAN POTASSIUM IN BULK AND PHARMACEUTICAL DOSAGE BY VISIBLE SPECTROPHOTOMETRY
}

\author{
D. Chandra Sekhar ${ }^{1,2}$, B. S. Diwakar ${ }^{1 *}$, P. Bhavani ${ }^{1}$, N. Madhavi ${ }^{3}$, \\ K. Raghu Babu ${ }^{4}$ and V. Jaganadha Rao ${ }^{5}$ \\ ${ }^{1}$ Department of Engineering Chemistry, Sagi Rama Krishnam Raju Engineering College, \\ Bhimavaram-534 204, (Andhra Pradesh) India \\ ${ }^{2}$ Department of Chemistry, Acharya Nagarjuna University, \\ Guntur-522 510(Andhra Pradesh) India \\ ${ }^{3}$ Department of Chemistry, JKC College, Guntur-522 006, (Andhra Pradesh) India \\ ${ }^{4}$ Department of Engineering Chemistry, AU College of Engineering (A), Andhra University, \\ Visakhapatnam-530 003, (Andhra Pradesh) India \\ ${ }^{5}$ Department of Engineering Chemistry, ANITS, Visakhapatnam-531 162,(Andhra Pradesh) \\ India-531 162 \\ *E-mail: bsd2020@gmail.com
}

\begin{abstract}
Losartan Potassium was determined by straight, simple and sensitive spectroscopic methods (M1 and M2) in bulk, pharmaceutical dosage forms. Those methods depend upon the nature of tertiary nitrogen in the tetrazole ring by forming a color complex with cobalt thiocyanate and ion association complex with acidic dye Tpooo with absorption maxima of $625 \mathrm{~nm}$ for M1 and $485 \mathrm{~nm}$ in M2. By following beers law the concentrations were in the range of $50-250 \mu \mathrm{g} / \mathrm{mL}$ in $\mathrm{M} 1$ and in $\mathrm{M} 2$ the concentration series of 10-40 $\mu \mathrm{g} / \mathrm{mL}$. The methods whichbedeveloped had been validated by detection, linearity, precision, and accuracy. This study can be helpful for the determination of drugs in pharmaceutical research with a good percentage of recovery, exactness, and precession. The outcome indicated that the proposed methods were productively used in the LSP estimation in massive and dosage form lacking any excipients. Furthermore, the results were validated statistically by repeatability and recovery studies.
\end{abstract}

Keywords: Cobalt Thiocyanate (CTC), Tpooo, Beer's law, Losartan Potassium (LSP), Ion association complex.

(c) RASĀYAN. All rights reserved

\section{INTRODUCTION}

Hypertension is an important health problem of humans since it is asymptomatic, which leads to coronary heart disease and stroke. There are several drugs to control hypertension, among them Losartan potassium is an important drug which belongs to Angiotensin Receptor Blocker ${ }^{1}$ (ARBs) class. The Angiotensin was formed by angiotensin-converting enzyme (ACE) activity, which attacks the angiotensin receptors. The attachment of Angiotensin to the receptors causes the muscle cells contraction in the blood vessels to which narrows blood vessels and leads to a rise in blood pressure. LSP antagonizes the angiotensin receptor through blocking the action of angiotensin, thereby relaxing muscle cells which dilate blood vessels and reduce the blood pressure. LSP is chemically known as2-n-butyl-4-chloro-5-hydroxymethyl1-(2-1H-tetrazole-5-yl)(biphenyl-4-yl)methyl imidazole potassium (Fig.-1). LSP can be used for treating hypertension, heart strokes as well as type II diabeties ${ }^{2}$. It has been authorized in Indian, British and

Rasayan J. Chem., 11(4), 1757-1764(2018)

http://dx.doi.org/10.31788/RJC.2018.1145016

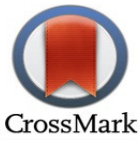


United State Pharmacopoeia(IP,BP, and USP). LSP was well studied by titration and chromatographic methods in USP,IP, and $\mathrm{BP}^{3-5}$. According to literature, there are few physic-chemical methods for the determining LSP in pharmaceutical formulations like UV ${ }^{6-12}$, RPHPLC ${ }^{13-17}$, HPLC ${ }^{18-21}$, HPTLC ${ }^{22-23}$, capillary electrophoresis and supercritical fluid chromatography ${ }^{24-25}$, Cathodic Adsorptive stripping voltammetry $^{26}$. The functional groups of LSP are not well exploited to design a suitable spectroscopic method for the determination of LSP. In this connection, there is a need to develop a flexible spectroscopic method to determine LSP for the investigations based on different chemical reactions. In the present work, two visible spectroscopic procedures based on the reaction of LSP with CTC and Tpooowere developed by forming stable colored complexes in bulk and dosage form of LSP.

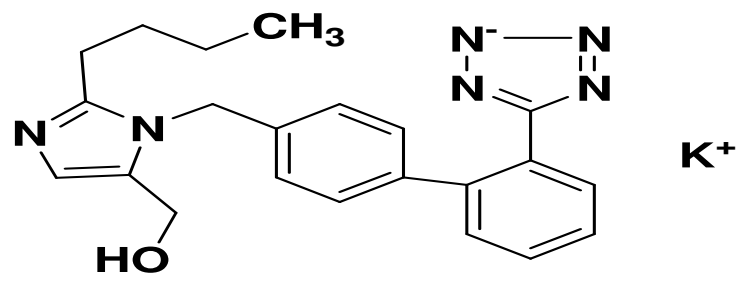

Fig.-1: Losartan Potassium(LSP) Structure

\section{EXPERIMENTAL}

\section{Materials and Methods}

Cobalt nitrate $\left(\mathrm{Co}\left(\mathrm{NO}_{3}\right)_{2}, \mathrm{BDH}\right)$, Ammonium thiocyanate $\left(\mathrm{NH}_{4} \mathrm{SCN}, \mathrm{BDH}\right)$, TPooo (Loba: 0.5\%w/v), Nitrobenzene, Potassium Chloride( $\mathrm{KCl})$, Hydrochloric acid $(\mathrm{HCl})$, Chloroform $\left(\mathrm{CHCl}_{3}\right)$ were purchased from local vendors and used as received. Losartan Potassium was received from IHCL lab, Vijayawada as a gift sample and LSP tablets (Repace tablets of Sun Pharmaceuticals, Assorted tablets of AS Pharmaceuticals) was purchased in the local drug store. The spectroscopic analysis was done by Elico SL 218 UV-Visible spectrophotometer. An equiptronics digital $\mathrm{P}^{\mathrm{H}}$ meter has been used for $\mathrm{P}^{\mathrm{H}}$ determinations.

\section{Standard Drug Solution Preparation}

The standard drug solution has been prepared by mixing $100 \mathrm{mg}$ losartan potassium and $100 \mathrm{~mL}$ of distilled water. The solution then was diluted until the standard drug solution concentration was 100 $\mu \mathrm{g} / \mathrm{mL}$ and further stored at $4^{0}$ C.A standard solution series were then freshly prepared during analysis.

\section{Reagent Preparation}

CTC solution $\left(2.5 \times 10^{-1} \mathrm{M}\right)$ was prepared by dissolving cobalt nitrate $(7.25 \mathrm{~g})$ and ammonium thiocyanate $(3.8 \mathrm{~g})$ into $100 \mathrm{~mL}$ deionized water.

A buffer solution of $\mathrm{P}^{\mathrm{H}} 2$ has been prepared by addition of $25 \mathrm{~mL}$ of $\mathrm{KCl}$ solution $(0.2 \mathrm{M})$ and $13 \mathrm{~mL}$ of $\mathrm{HCl}(0.2 \mathrm{M})$ in a $100 \mathrm{~mL}$ volumetric flask.

Tpooo solution $\left(1.43 \times 10^{-2} \mathrm{M}\right)$ has been prepared by adding Tpooo $(500 \mathrm{mg})$ in $100 \mathrm{~mL}$ deionized water.

\section{Sample Solution Preparation}

Two batches of sample solutions were prepared by weighing the LSP tablets of two different companies. The tablets were weighed $(100 \mathrm{mg}$ ), pulverized and dispersed in $25 \mathrm{~mL}$ of isopropyl alcohol by sonication for $15 \mathrm{~min}$ and then filtered. The filtrate obtained was evaporated to dryness and the residue was utilized for sample solution prepared as described in the above process.

\section{RESULTS AND DISCUSSION}

\section{Spectroscopic Determination of Wavelength Maximum( $\lambda$ max) \\ Method $M_{1}$}

A series of $125 \mathrm{~mL}$ separating funnels are taken and totally different parts of standard LSP solutions (1.0 $-5.0 \mathrm{~mL}, 2.50 \mu \mathrm{g} / \mathrm{mL}$ ) were delivered into those funnels. $7.0 \mathrm{~mL}$ of CTC solution, $3.0 \mathrm{~mL}$ of $\mathrm{pH} 2.0$ 
RASĀYAN J. Chem.

Vol. 11 | No. 4 |1757 - 1764| October - December | 2018

buffer solution were then other to the funnels and the total volume of binary compound introduce each in every funnel is adjusted to fifteen $\mathrm{mL}$ with deionized water. $10 \mathrm{~mL}$ of organic phase nitrobenzene was other to each separating funnel and also the mixture was jolted for 2 minutes. Then phases were allowed to separate and also the absorbance of the divided nitrobenzene layer was measured at $635 \mathrm{~nm}$. The colored species were steadily tended for one hour. With the help of a calibration graph(Fig.-2), the amount of LSP was calculated to present in the sample solution.

\section{Method $\mathbf{M}_{2}$}

Different volumes of standard drug solutions $(1.25-6.25 \mathrm{~mL}, 250 \mu \mathrm{g} / \mathrm{mL})$ were taken independently in a various $125 \mathrm{~mL}$ separating funnels. $0.1 \mathrm{M}$ Hydrochloric acid $2.0 \mathrm{~mL}$ and Tpooo1.5 mL were added into the funnels. The whole amount of the aqueous phase was made up with deionized water $10.0 \mathrm{~mL}$. Then $10.0 \mathrm{~mL}$ of carbon tetrachloride was added to each separating funnel, shook for 2 minutes and permitted to separate the carbon tetrachloride layer was collected by the cotton block, was measured the absorbance at $485 \mathrm{~nm}$ against a reagent blank (Fig.-3). The two-color species were steady for 4 hours.
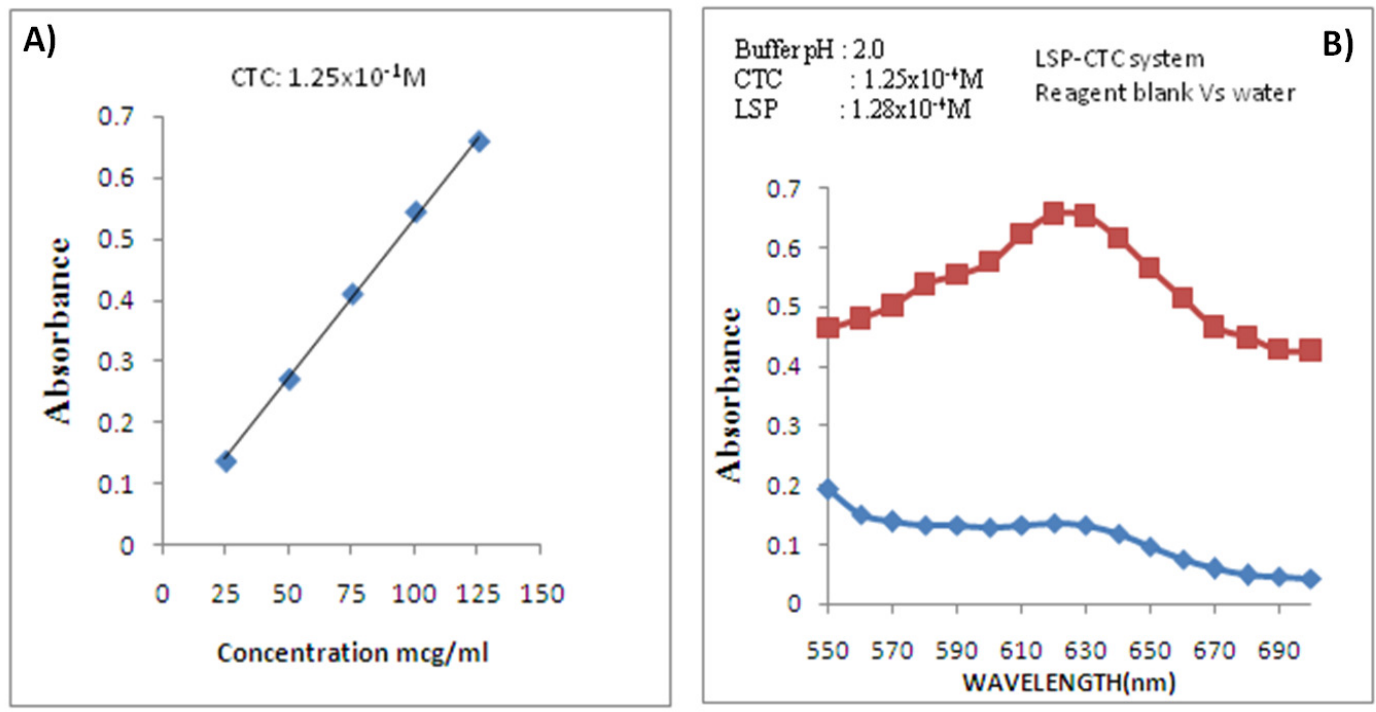

Fig.-2: (A) Beers Law Plot of LSP with CTC System and (B) Absorption Spectra of LSP with CTC System (Red) and its Reagent Blank (Blue)
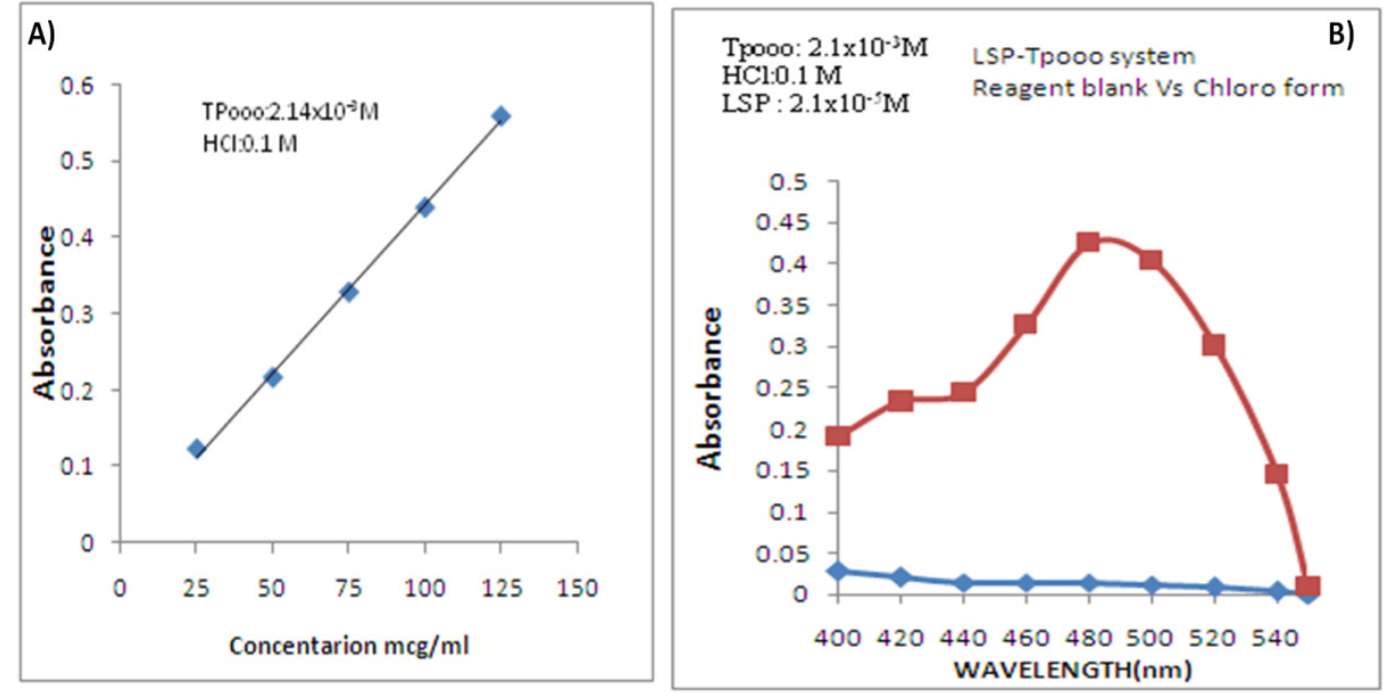

Fig.3: (A) Beer's law plot of LSP withTpooosystem and (B) Absorption spectra of LSP with Tpooo system (Red) and reagent blank (Blue) 
RASĀYAN J. Chem.

Vol. 11 | No. 4 |1757 - 1764| October - December | 2018

Initially to optimize the operational conditions utilized in the methods were established by implementing a variation of 1 variable at a time (OVAT) methodology. The optimum conditions for the ways Method1, Method 2 were given in Table- 1 and 2. The influence of time, volume, the strength of reagents, acid solution and solvent for a final dilution of the colored complex were investigated. So as to check, whether or not the colored species are created or diminished within the higher than developed methodology was confirmed by Beer-Lambert's absorbance at applicable wavelengths of solutions containing totally different amounts of LSP and such amounts of reagents (as represented within the tended procedures of every method) be noted. The Beer-Lambert's plots of the systems were illustrated diagrammatically (Fig.-2 and 3). From the graph, the coefficient of correlation and intercept were calculated by victimizationLeast square regression analysis methodology. The optical characters like Beer's law limits, percent relative standard deviation,Sandell's sensitivity, molar extinction coefficient were calculated for all the methodologies and also the results square measure given in Table- 1 . Regression characteristics like standard deviation of slope $(\mathrm{Sb})$, standard deviation of intercept (Sa),standard error of estimation (Se), \% range of error were calculated for each the methods and square measure are shown in Table-3.

Table-1: Optimum Conditions for Method M1

\begin{tabular}{|c|c|c|c|}
\hline Parameter & $\begin{array}{l}\text { Optimum } \\
\text { Range }\end{array}$ & $\begin{array}{l}\text { Conditions in } \\
\text { Procedure }\end{array}$ & Remarks \\
\hline$\lambda_{\max (\mathrm{nm})}$ & $615-635$ & 625 & \\
\hline $\begin{array}{c}\mathrm{pH} \text { effect on } \\
\text { absorbance values }\end{array}$ & $1.5-2.5$ & 2.0 & $\begin{array}{l}\text { Variation of } \mathrm{pH} \text { of the buffer shows low absorbance } \\
\text { values in upper and lower limits. }\end{array}$ \\
\hline $\begin{array}{l}\text { Buffer solution } \\
\text { required for the } \\
\text { utmost intensity of the } \\
\text { color (ml) }\end{array}$ & $2.0-4.0$ & 3.0 & $\begin{array}{l}2.0 \mathrm{ml} \text { of buffer } \mathrm{pH} 2.0 \text { found to be necessary for } \\
\text { aqueous phase for maximum color development in } \\
\text { nitrobenzene layer. }\end{array}$ \\
\hline $\begin{array}{l}\text { Effect of volume of } \\
\text { CTC required for } \\
\text { complex formation } \\
(\mathrm{ml})\end{array}$ & $6.0-8.0$ & 7.0 & $\begin{array}{l}\text { A minimum of } 6.0 \mathrm{ml} \text { of CTC was required for color } \\
\text { formation and to cover the broad range of Beer's law } \\
\text { limits. }\end{array}$ \\
\hline $\begin{array}{l}\text { Selection of organic } \\
\text { solvent for colored } \\
\text { complex extraction. }\end{array}$ & Nitrobenzene & Nitrobenzene & $\begin{array}{l}\text { Among } \sim \text { the various solvents tried for extraction } \\
\text { (chloroform, chlorobenzene, dichloromethane, carbon } \\
\text { tetrachloride, benzene, and n-butanol), nitrobenzene } \\
\text { was found to be better due to higher sensitivity. }\end{array}$ \\
\hline $\begin{array}{l}\text { Aqueous and organic } \\
\text { phase ratio effect on } \\
\text { extraction. }\end{array}$ & $3: 2$ & $3: 2$ & $\begin{array}{l}\text { The ratio of aqueous to organic phase } 3: 2 \text { was } \\
\text { necessary for the efficient extraction of the complex. }\end{array}$ \\
\hline $\begin{array}{l}\text { Shaking time effect } \\
\text { (min) }\end{array}$ & $1-5(\min )$ & $2(\min )$ & $\begin{array}{l}\text { Stable absorbance values are obtained for the shaking } \\
\text { period of } 1-5 \mathrm{~min} \text {. }\end{array}$ \\
\hline $\begin{array}{l}\text { Stability of the species } \\
\text { (min) }\end{array}$ & $\begin{array}{l}\text { Immediate to } \\
\quad 60\end{array}$ & 10 & $\begin{array}{l}\text { The colored species was stable for } 60 \mathrm{~min} \text { in the organic } \\
\text { phase. Afterward, the absorbance slowly decreased. }\end{array}$ \\
\hline \multicolumn{4}{|c|}{ Table-2: Optimum Conditions for Method $\mathrm{M}_{2}$} \\
\hline Parameter & $\begin{array}{l}\text { Optimum } \\
\text { range }\end{array}$ & $\begin{array}{l}\text { Conditions in } \\
\text { procedure }\end{array}$ & Remarks \\
\hline$\lambda_{\max }(\mathrm{nm})$ & $480-580$ & 485 & \\
\hline Acid concentration effect. & $\left|\begin{array}{ll}0.08-0.12 & \mathrm{M} \\
\mathrm{HC} 1 & \end{array}\right|$ & $0.10 \mathrm{M} \mathrm{HCl}$ & $\begin{array}{l}\text { Variation of the concentration of the acid further than } \\
\text { the upper and lower limits resulted in low absorbance } \\
\text { values. }\end{array}$ \\
\hline
\end{tabular}


RASĀYAN J. Chem.

Vol. 11 | No. 4 |1757 - 1764| October - December | 2018

\begin{tabular}{l|l|l|l}
\hline $\begin{array}{l}\text { The volume of acid or } \\
\text { buffer necessary for the } \\
\text { highest intensity of the }\end{array}$ & $1.7-2.2$ & 2.0 & $\begin{array}{l}\text { Variation of the volume of acid or buffer within the } \\
\text { optimum range resulted in constant absorbance values. }\end{array}$ \\
\hline $\begin{array}{l}\text { The volume of dye } \\
\text { TPoooeffect (ml) }\end{array}$ & $1.3-1.7$ & 1.5 & $\begin{array}{l}\text { The specified volumes of respective dyes were required } \\
\text { for covering the wide range of Beer's law limits. }\end{array}$ \\
\hline $\begin{array}{l}\text { selection of the organic } \\
\text { solvent for extraction of } \\
\text { the colored complex. }\end{array}$ & Chloroform & Chloroform & $\begin{array}{l}\text { The other water incompatible solvents checked for the } \\
\text { extraction of the colored complex into organic phase } \\
\text { include chlorobenzene, dichloromethane, carbon } \\
\text { tetrachloride, n-butanol, and benzene. Chloroform was } \\
\text { most popular for its selective extraction of the colored } \\
\text { drug-dye complex from the aqueous phase. }\end{array}$ \\
\hline $\begin{array}{l}\text { Aqueous and organic } \\
\text { phase ratio effect on } \\
\text { extraction. }\end{array}$ & $1: 1$ & $1: 1$ & $\begin{array}{l}\text { The extraction of the colored species within the } \\
\text { chloroform phase was incomplete as the ratio of } \\
\text { aqueous to organic layer be more than the specific ratio } \\
\text { in each case. }\end{array}$ \\
\hline $\begin{array}{l}\text { Effect of shaking time } \\
\text { (min) }\end{array}$ & $1-5$ & 2 & $\begin{array}{l}\text { Constant absorbance values were obtained for the } \\
\text { shaking period of 1-5 minutes. }\end{array}$ \\
\hline $\begin{array}{l}\text { Temperature effect on the } \\
\text { colored species. }\end{array}$ & $\begin{array}{lll}\text { Lab. temp. } \\
(28 \pm 5)\end{array}$ & $\begin{array}{l}\text { Lab. temp. } \\
(28 \pm 5)\end{array}$ & $\begin{array}{l}\text { The extraction of the colored species at low temperature } \\
\left(<20^{\circ} \mathrm{C}\right) \text { was found to be improper and at high } \\
\left.\text { temperatures }>35^{\circ} \mathrm{C}\right) \text { the steadiness of the colored } \\
\text { species was found to be less. }\end{array}$ \\
\hline $\begin{array}{l}\text { Stability of the colored } \\
\text { species }\end{array}$ & $\begin{array}{l}\text { Immediate } 4.0 \\
\text { hrs }\end{array}$ & 10 (min) & $\begin{array}{l}\text { The colored species in the organic layer was stable for } \\
4.0 \text { hrs. Afterward, the absorbance gradually decreased. }\end{array}$ \\
\hline
\end{tabular}

Moreover, industrial formulations were with success analyzed by the developed strategies. The values obtained by the developed and reference methods be compared statistically by the t-test and F-test and also the results found that there were no evident variations. Accuracy and recovery experiments were disbursed by adding a known quantity of the drug to the pre-analyzed formulations and the results are given in Table-4.

Table-3: Optical and Regression Characteristics, Precision and Accuracy of the Proposed Methods for LSP

\begin{tabular}{c|c|c}
\hline Parameter & M1 & M2 \\
\hline$\lambda_{\max }(\mathrm{nm})$ & 625 & 485 \\
\hline Beer's law limits $(\mu \mathrm{g} / \mathrm{mL})$ & $50-250$ & $10-40$ \\
\hline Detection limits $(\mu \mathrm{g} / \mathrm{mL})$ & $0.0445 \times 10^{-2}$ & $0.0545 \times 10^{2}$ \\
\hline Molar absorptivity $(\mathrm{lit} / \mathrm{mole} / \mathrm{cm})$ & $5.001 \times 10^{4}$ & $4.056 \times 10^{4}$ \\
\hline Sandels sensitivity $\left(\mu \mathrm{g} / \mathrm{cm}^{2}\right)$ & 3.6832 & 4.5454 \\
\hline Slope $(\mathrm{b})$ & $5.3 \times 10^{-3}$ & $4.401 \times 10^{-3}$ \\
\hline Standard deviation of slope $\left(\mathrm{S}_{\mathrm{b}}\right)$ & $9.49 \times 10^{-5}$ & $9.655 \times 10^{-5}$ \\
\hline Intercept $(\mathrm{a})$ & 0.0083 & 0.006 \\
\hline Standard deviation of intercept $\left(\mathrm{S}_{\mathrm{a}}\right)$ & $7.8686 \times 10^{-3}$ & $8.001 \times 10^{-3}$ \\
\hline Standard error of estimation $\left(\mathrm{S}_{\mathrm{e}}\right)$ & 0.0086 & 0.00877 \\
\hline Correlation coefficient & 0.9989 & 0.9982 \\
\hline Relative standard deviation $(\%) *$ & 0.3385 & 0.2034 \\
\hline
\end{tabular}


RASĀYAN $J$. Chem.

Vol. 11 | No. 4 |1757 - 1764| October - December | 2018

\begin{tabular}{c|c|c}
\hline \% range of error(confidence limits) & & \\
\hline 0.05 level & 0.3892 & 0.5219 \\
\hline 0.01 level & 0.6103 & 0.9728 \\
\hline
\end{tabular}

Table-4: analysis of LSP in pharmaceutical formulations by proposed and reference methods.

\begin{tabular}{|c|c|c|c|c|c|c|c|}
\hline \multirow[t]{2}{*}{ Method } & \multirow[t]{2}{*}{ \$formulations } & \multirow{2}{*}{$\begin{array}{l}\text { Labeled } \\
\text { amount } \\
(\mathrm{mg})\end{array}$} & \multicolumn{3}{|c|}{ Found by proposed methods } & \multirow{2}{*}{$\begin{array}{l}\text { Found by } \\
\text { reference } \\
\text { method } \pm \text { SD }\end{array}$} & \multirow{2}{*}{$\begin{array}{c}* \% \text { recovery } \\
\text { by proposed } \\
\text { methods }+S D\end{array}$} \\
\hline & & & $\wedge \wedge$ amount found \pm SD & $\mathrm{T}$ & $F$ & & \\
\hline \multirow[t]{2}{*}{$\mathrm{M}_{1}$} & Batch - 1 & 50 & $49.90 \pm 0.10$ & 0.41 & 3.06 & $49.96 \pm 0.19$ & $99.54 \pm 0.075$ \\
\hline & Batch -2 & 50 & $49.90 \pm 0.10$ & 1.41 & 1.74 & $49.93 \pm 0.12$ & $99.39 \pm 0.21$ \\
\hline \multirow[t]{2}{*}{$\mathrm{M}_{2}$} & Batch -1 & 50 & $49.95 \pm 0.15$ & 0.41 & 3.06 & $49.96 \pm 0.18$ & $99.60 \pm 0.06$ \\
\hline & Batch -2 & 50 & $49.90 \pm 0.10$ & 0.11 & 1.58 & $49.95 \pm 0.15$ & $99.496 \pm 0.19$ \\
\hline
\end{tabular}

${ }^{\$}$ Different batches as of two different companies (Batch-1 Asortan tablets of AS Pharmaceuticals, Batch2Repacetablets of Sun Pharmaceuticals.)

${ }^{\wedge}$ average $\pm \mathrm{SD}$ of 6 determinations, the $\mathrm{t}$ and $\mathrm{F}$ values refer to the comparison of the proposed method with the reference method (UV). * Recovery of $10 \mathrm{mg}$ added to the pre-analyzed sample (average of three determinations). Reference method (reported UV method) using 2D water $\left(\lambda_{\max }=249 \mathrm{~nm}\right)$.

\section{Chemistry of Colored Species}

LSP possesses two different moieties, tetrazole, and imidazole. The proposed methods are based on top of the characteristics of reactive functional groups in LSP. The tertiary nitrogen in tetrazole ring forms the colored complex with CTC in method $\mathrm{M}_{1}$ and with acidic dye Tpoooion association complex in method $\mathrm{M}_{2}$.

\section{Method $M_{1}$}

The blue colored complex formed between drug and CTC will be attributed to the presence of cyclic tertiary nitrogen (more basic one) in tetrazole portion. The probable sequence of reaction supported analogy is bestowed in below schematic diagram:

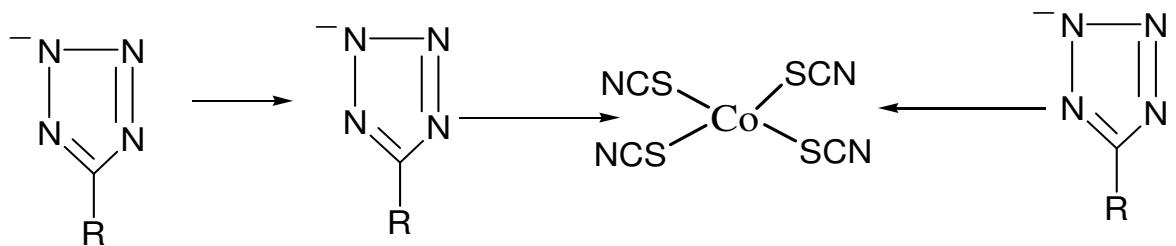<smiles>[R]Cc1cccc(-c2ccc(Cn3c(CO)cnc3CCCC)cc2)c1</smiles>

Scheme-1

\section{Method $\mathbf{M}_{2}$}

The tertiary amine group within the drug might kind an ion-association complex with acidic dye (TPooo $\mathrm{M}_{2}$ ) which might be isolated into chloroform from the aqueous phase. The protonated nitrogen (positive of drug molecule) in acidic medium is predicted to draw in the charged a part of the dye and behave as one unit being control along by electrostatic attraction. The slop quantitative relation methodology of 
RASĀYAN J. Chem.

Vol. 11 | No. 4 |1757 - 1764| October - December | 2018

study unconcealed the drug to dye mole quantitative relation as 1:1. The supported analogy the structure of ion association complexes are shown in below schematic diagram.

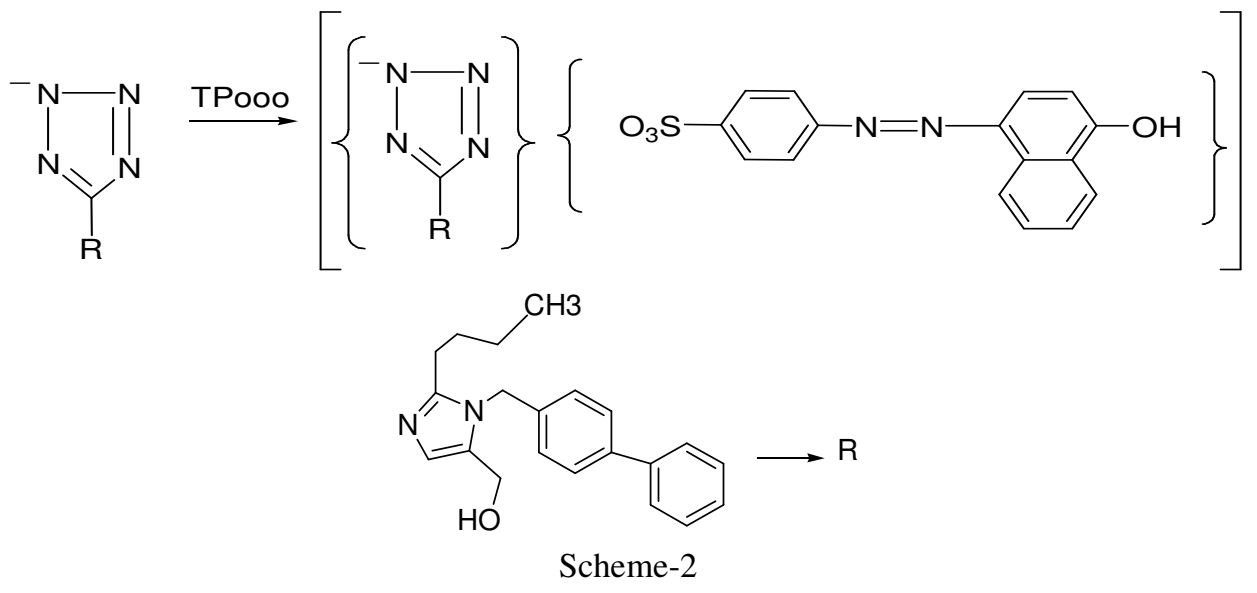

\section{CONCLUSION}

The projected strategies for LSP determination have several benefits over different analytical strategies due to its rapidity, economic and environmental safety. These methods are superior to HPLC, HPTLC, GCMS procedures because it needs less skill. The developed methods have a higher degree of accuracy and precession within the determination of Losartan Pottasiumin order that these projected methods may be extended for the routine assay of LSP formulations in Pharmaceutical Industries.

\section{ACKNOWLEDGMENT}

The authors are thankful to Principal, SRKR Engineering College, Bhimavaram for continuous encouragement and ResearchLabs of Dept. of Engineering Chemistry, Andhra University, Visakhapatnam for providing spectroscopic analysis.

\section{REFERENCES}

1. http://www.medicinenet.com/angiotensin_ii_receptor_blockers/article.htm

2. http://www.medicinenet.com/diabetes_mellitus/article.htm

3. Indian Pharmacopeia, Ministry of Health and Family Welfare, 6th Edition, Indian Pharmacopeia Commission, Ghaziabad, India, 2, 1607-1609(2010).

4. United Statepharmacopeia-34 and National Formulary-29, Second Supplement, United State Pharmacopoeial Convention, USA, Vol II \& III, 3342-3343(2011).

5. British pharmacopeia, 6th edition, British Pharmacopeia Commission Office, London, Vol I \& II, 1295-1297(2010).

6. P.L.K.M. Rao, V. Venugopal, K. G. Anil, B. Rajesh, G.A.L. Prasad, Ravinder Goud., Int. J. of Res. in Pharm. \& Chem., 1(3), 295(2011)

7. A. Zehra, W. Nimra, N. Erum, A. Fatima, A. Taiba, M. Fatima, S. Syeda, A. Maria, Global J. Of Med. Res., 15, 34(2015).

8. P. R. Topale, N. J. Gaikwad, M. R. Tajane, Indian Drug, 40, 645(2003)

9. D. S. Chandra, R. B. Desireddy, K. P. Jitendra, N. Suresh, G. Sravankumar, A. Ramanareddy, R. N. Raja, Int. J. of Chem. \& Pharm. Sci., 3(3) ,76(2012)

10. N. Safila, Global J. of Med. Res., 14,14(2014).

11. O. C. Lastra, I. G. Lemus, H. J. Sánchez, R. F. Pérez, J. Pharm. Biomed. Anal., 33(2), 175(2003)

12. C. Ramesh, G. N. Reddy, T. V. Narayana, K. V. S. Prasad, B. Ganga Rao, Rasayan J. Chem., 4,113(2011).

13. K. Kathiresan. S. Gothandaraman, M. M. Swamivel, K. S. Mathan, R. Manavalan, Rasayan J. Chem, 1, 521(2008). 
RASĀYAN J. Chem.

Vol. 11 | No. 4 |1757 - 1764| October - December | 2018

14. S. J. Dipali, D.W. Deepali, D. D.Pradip, D. R. Mundhada, Int. J. of PharmTech Research,4, 1581(2012).

15. R. K. Srinivasa, K. Srinivas, Indian J. Pharm. Sci., 72, 108(2010), DOI: 10.4103/0250-474X.62243

16. D. Ramkumar, K. B. Vidhya, R. D. Sunil, Sci. Pharm. 79, 545(2011), DOI:10.3797/scipharm.110513

17. A. P. Harshal, K. G. Lalitha, Chromatography Research International, (2014), DOI: $10.1155 / 2014 / 736761$

18. M. A. Hinge, V. M. Bhanusali, J. M. Rajiv, Analytical Chemistry Letters, 6, 408(2016), DOI: $10.1080 / 22297928.2016 .1206834$

19. D. L. Hertzog, J. F. McCafferty, X. Fang, R. J. Tyrrell, R. A. Reed, Journal of Pharmaceutical and Biomedical Analysis, 30, 747(2002).

20. B. Pravin, B. M. Rao, P. Madhavan, N. Someswara Rao, Rasayan J. Chem.,3(1),87(2010).

21. T. Sivakumar, P. Venkatesan, R. Manavalan, K. Valliappan, Indian J. Pharm. Sci.,69, 154(2007).

22. K. E. McCarthy, Q. Wang, E.W. Tsai, R.E.Gilbert, D. P. Ip, M. A. Brooks, Journal of Pharmaceutical and Biomedical Analysis, 17, 671(1998).

23. S. L. Karunanidhi, L. Sivasubramanian, J. Anal. Methods. Chem.,(2012)

24. S. Hillaert, W. Van den Bossche, J. Pharm. Biomed. Anal.,,31, 329(2003).

25. R. C. Williams, M. S. Alasandro, V. L. Fasone, R. J. Boucher, J. F. Edwards, J. Pharm. Biomed. Anal., 14, 1539(1996).

26. A. E. Ali, H. Reza, Analytical Sciences, 24, 1449(2008).

[RJC-5016/2018] 